\title{
Strategies to Improve Urban Water Delivery in West Bengal, India: An Analysis of Water Institutions and Benchmarking Of Water Delivery Organizations
}

\author{
Tirthankar Nag \\ Amit Garg
}

W.P. No. 2013-04-02

April 2013

The main objective of the working paper series of the IIMA is to help faculty members, research staff and doctoral students to speedily share their research findings with professional colleagues and test their research findings at the pre-publication stage. IIMA is committed to maintain academic freedom. The opinion(s), view(s) and conclusion(s) expressed in the working paper are those of the authors and not that of IIMA.

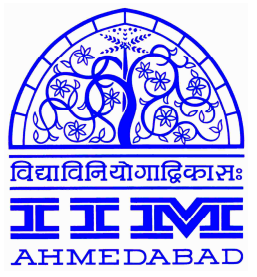

INDIAN INSTITUTE OF MANAGEMENT

AHMEDABAD-380 015

INDIA 


\title{
Strategies to Improve Urban Water Delivery in West Bengal, India: An Analysis of Water Institutions and Benchmarking Of Water Delivery Organizations
}

\author{
Tirthankar Nag \\ Visiting Faculty, Indian Institute of Management Ahmedabad \\ Amit Garg \\ Professor, Indian Institute of Management Ahmedabad \\ Email: amitgarg@iimahd.ernet.in
}

\begin{abstract}
The study examines the status of urban water delivery in India through a case study of the state of West Bengal in India. The state has been selected as a unit of study to bring out the regional variances that are not captured at a more aggregate or country level study. The study focuses on various types of urban local bodies in the state, the organizational and institutional structure for water delivery and issues around them. The study also benchmarks various urban local bodies for their water service delivery through data envelopment analysis. The study finds that in the current state of fragmented institutions and shared responsibilities between various water organizations, there needs to be a focused policy guideline for integrated development of the water sector in the state. The study also identifies certain categories of urban local bodies, for which there are further scope for efficiency improvement.
\end{abstract}

Keywords: Urban Water; Benchmarking; Water Institutions; DEA 
Strategies to Improve Urban Water Delivery in West Bengal, India: An Analysis of Water Institutions and Benchmarking Of Water Delivery Organizations

\section{Contents}

1. INTRODUCTION

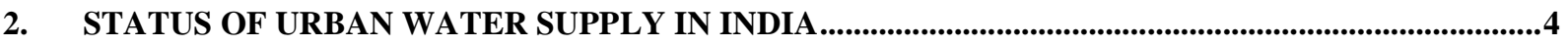

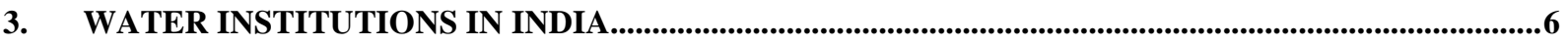

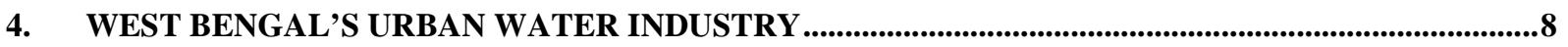

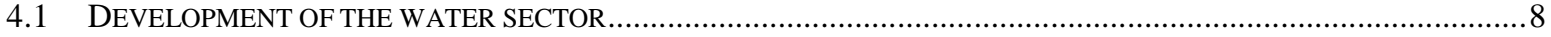

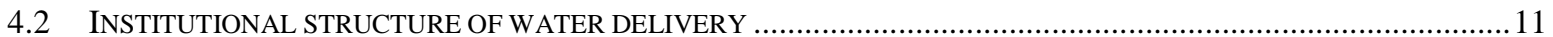

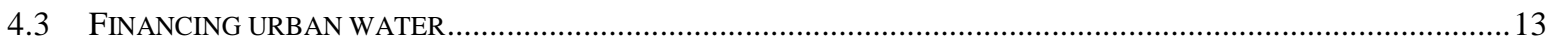

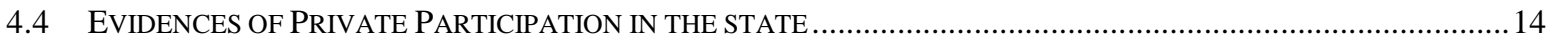

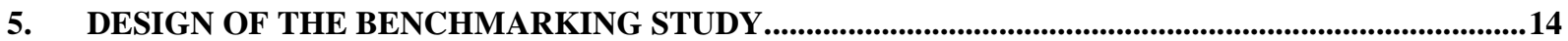

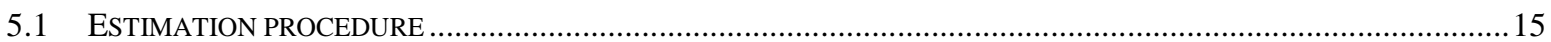

5.2 DATA DESCRIPTION

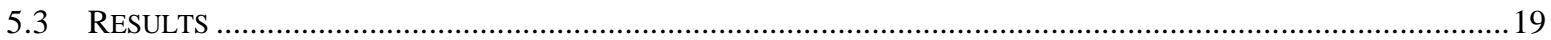

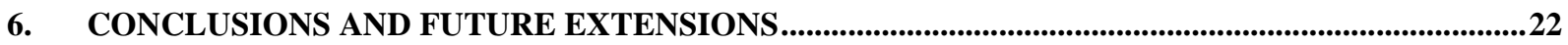

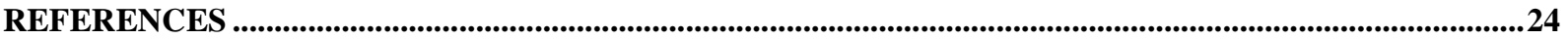




\section{Introduction}

India and China with one third of the world's population have less than ten percent of the world's water resources. A fresh water crisis may be in the offing for two thirds of the global population within next quarter century (Barlow and Clarke, 2003; IPCC, 2007). In addition countries like India suffer from huge spatial and temporal disparities in distribution of water with its north-eastern region receiving more than a hundred times more rainfall than its western part and that too concentrated mostly during the summer monsoons (The Economist, 2010). Expanding urban population without a proportional increase in civic amenities is already putting pressure on water resource management in urban centres. By 2025, half of India's population will live in urban areas and face issues around water (Planning Commission, 2002). These bring more into focus on the institutional arrangements and delivery mechanisms of this scarce and non-substitutable resource.

Studies carried out on developing countries over the last three decades suggest that the theoretical rationale for reforms is mostly grounded on arguments for efficiency, effectiveness and fiscal sustainability (Araral, 2010). Other studies stress that water utilities need to build close relationships with customers and implement customer service indicators for tracking their performance (Aguilar-Benitez, Saphores, 2010). The present study examines the growth of urban water institutions and water supply provisions by urban local bodies. The methodology includes a review of the literature to construct the institutional structure and the institutional changes taking place in the sector. The study of the institutional mechanism is supplemented by a benchmarking study of urban local bodies in the state of West Bengal to examine the status of water delivery under different urban local bodies and draw insights on delivery mechanisms.

\section{Status of urban water supply in India}

India has 13 cities over 2 million population, 33 over one million, and 298 over hundred thousand population (figure 1). Supplying water to the urban centres is a major concern due their expanding sizes. According to the national water policy, drinking water has been given the highest priority. There have been limited efforts at creation of new surface water sources and ground water tables have been steadily declining. None of the urban centres in India have 24 hours water supply, though there are efforts to make it a reality through some of the government funded projects. A study on 20 cities in India showed that around $80 \%$ of the urban population are covered by water supply systems. The urban centres had only 4.3 hours of water supply on an average per day with $30 \%$ of the water being lost in transmission (ADB, 2007). A summary of the urban water supply system in India is provided in Table 1.

Other issues revolve around poor water quality, inadequate service delivery mechanisms and poor financial conditions of the urban local bodies who are burdened with the operation and maintenance responsibilities of the water supply system. Also a considerable portion of the waste water goes untreated which could have resolved some of the supply issues for non-drinking water. 
Figure 1: Population of major Indian cities

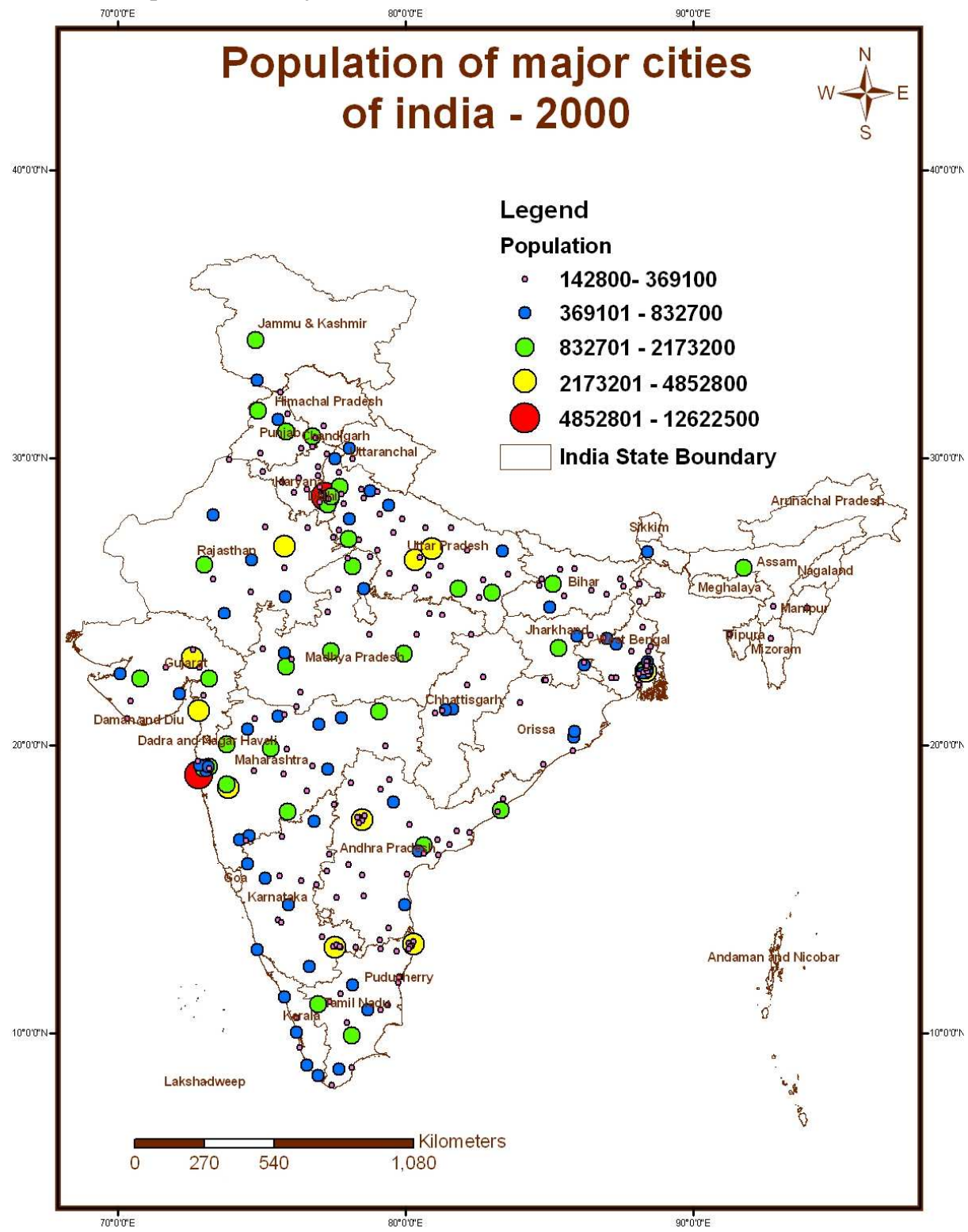

Note: Data sourced from Census of India (2001)

Table 1: Urban water supply in selected Indian cities (2007)

\begin{tabular}{l|rrrrrr}
\hline Cities & $\begin{array}{r}\text { Water } \\
\text { Coverage }\end{array}$ & $\begin{array}{r}\text { Water } \\
\text { Availability }\end{array}$ & $\begin{array}{r}\text { Consumption } \\
\text { (litre)/Capita/day }\end{array}$ & $\begin{array}{r}\text { Unaccounted } \\
\text { for Water }\end{array}$ & $\begin{array}{r}\text { Connections } \\
\text { Metered }\end{array}$ & $\begin{array}{r}\text { Average } \\
\text { Tariff }\end{array}$ \\
\hline & $\%$ & Hrs. & Icd & $\%$ & $\%$ & Rs./m ${ }^{3}$ \\
Kolkata & 79.0 & 8.3 & 130.0 & 35.0 & 0.1 & 1.1 \\
Mumbai & 100.0 & 4.0 & 191.0 & 13.0 & 75.0 & 4.6 \\
Chennai & 89.3 & 5.0 & 87.0 & 17.0 & 3.5 & 10.9 \\
Ahmedabad & 74.5 & 2.0 & 171.0 & & 3.0 & 1.4 \\
Amritsar & 75.7 & 11.0 & 86.0 & 57.0 & 4.0 & 9.3 \\
Bangalore & 92.9 & 4.5 & 74.0 & 45.0 & 95.5 & 20.6 \\
\hline
\end{tabular}




\begin{tabular}{l|rrrrrr}
\hline Bhopal & 83.4 & 1.5 & 72.0 & & & 0.6 \\
Chandigarh & 100.0 & 12.0 & 147.0 & 39.0 & 79.0 & 5.0 \\
Coimbatore & 76.1 & 3.0 & 109.0 & 41.0 & 100.0 & 3.7 \\
Indore & 77.3 & 0.8 & 87.0 & & 0.1 & 2.8 \\
Jabalpur & 75.2 & 4.0 & 139.0 & 14.0 & & 1.5 \\
Jamshedpur & 74.4 & 6.0 & 203.0 & 13.0 & 0.9 & 4.5 \\
Mathura & 70.0 & 2.0 & & & & 0.6 \\
Nagpur & 91.5 & 5.0 & 100.0 & 52.0 & 40.0 & 6.6 \\
Nashik & 92.6 & 3.5 & 93.0 & 60.0 & 80.0 & 4.3 \\
Rajkot & 98.1 & 0.3 & 101.0 & 23.0 & 0.4 & 5.1 \\
Surat & 77.4 & 2.5 & & & 1.9 & 1.7 \\
Varanasi & 77.7 & 7.0 & 147.0 & 30.0 & & 3.2 \\
Vijayawada & 70.5 & 3.0 & 158.0 & 24.0 & 6.0 & 2.2 \\
Visakhapatnam & 49.2 & 1.0 & 124.0 & 14.0 & 1.3 & 8.6 \\
Average & $\mathbf{8 1 . 2}$ & $\mathbf{4 . 3}$ & $\mathbf{1 2 3 . 3}$ & $\mathbf{3 1 . 8}$ & $\mathbf{2 4 . 5}$ & $\mathbf{4 . 9}$ \\
Max & $\mathbf{1 0 0 . 0}$ & $\mathbf{1 2 . 0}$ & $\mathbf{2 0 3 . 0}$ & $\mathbf{6 0 . 0}$ & $\mathbf{1 0 0 . 0}$ & $\mathbf{2 0 . 6}$ \\
Min & $\mathbf{4 9 . 2}$ & $\mathbf{0 . 3}$ & $\mathbf{7 2 . 0}$ & $\mathbf{1 3 . 0}$ & $\mathbf{0 . 1}$ & $\mathbf{0 . 6}$ \\
\hline Source: Compin
\end{tabular}

Source: Compiled from ADB Benchmarking Study, 2007

\section{Water Institutions in India}

Institutions are the rules of the game in a society or, more formally, are the humanely devised constraints that shape human interaction (North, 1981, 1994). Institutions may be both formal (law and regulations) or informal (generally accepted norms and codes) in nature. Since these rules are often formalized in terms of three inter-related aspects, i.e., legal framework, policy environment, and administrative arrangement, water institutions can be conceptualized as an entity defined interactively by its three main analytical components, i.e., water law, water policy, and water administration (Saleth, Dinar, 2000). Various endogenous and exogenous factors influence these three main institutional components.

Institutional arrangements governing the water sector are undergoing remarkable changes Worldwide (Saleth, Dinar, 2000). The provision of clean water, sanitation and disposal of storm-water to all the residents of large urban centers in developing countries will be one of the major challenges of the 21 st century (Biswas, 2006). Public sector monopolies in developing countries are often associated with inefficiencies and inability to meet rapidly growing demand (Araral, 2008).

India has a federal structure and the Indian constitution empowers the states to govern water resources. However, with the introduction of the $74^{\text {th }}$ constitutional amendment in 1992, devolution of authority towards the urban local bodies/ municipalities was preferred. The Urban Local Bodies (ULBs) are since vested with the constitutional right for planning, designing, implementing, and operation and maintenance of water and sanitation projects (Nallathiga, 2008). The federal government only plays an advisory role along with the national and state water policies which provide a broad guideline for 
the sector. However, at the local government level, there are significant variations in institutional arrangements across the country. A representation of the institutional structure is provided below in Figures 2 and 3.

Figure 2: Urban water Institutions in India

\begin{tabular}{|l|}
\hline \multicolumn{1}{|c|}{ Law } \\
\hline -State Acts for \\
Independent \\
Regulatory Authority ( 4 \\
states, impl. by \\
Maharashtra) \\
- Municipal Acts \\
- Use Priority \\
- Project Selection \\
- Cost Recovery \\
- Water Transfers \\
- Turnover/Devolution \\
-Privatization \\
- Technology Policy \\
\hline
\end{tabular}

\begin{tabular}{|l|}
\hline \multicolumn{1}{|c|}{ Policy } \\
\hline - National Water Policy, \\
2002 \\
- State Water Policies \\
(Introduced by 8 states) \\
- Inter-Source Links \\
- Inter-Resource Links \\
- Water Rights \\
- Conflict Resolution \\
-Accountability \\
- Scope for Private \\
Participation \\
\end{tabular}

\begin{tabular}{|l|}
\hline \multicolumn{1}{|c|}{ Administration } \\
\hline -Water Supply \\
-Waste Management \\
- InvestmentDecisions \\
- Operation and \\
Maintenance \\
-Water Tariff Setting \\
-Water Purchase \\
Agreements \\
- Loss management \\
\end{tabular}

Figure 3: Levels of water organizations

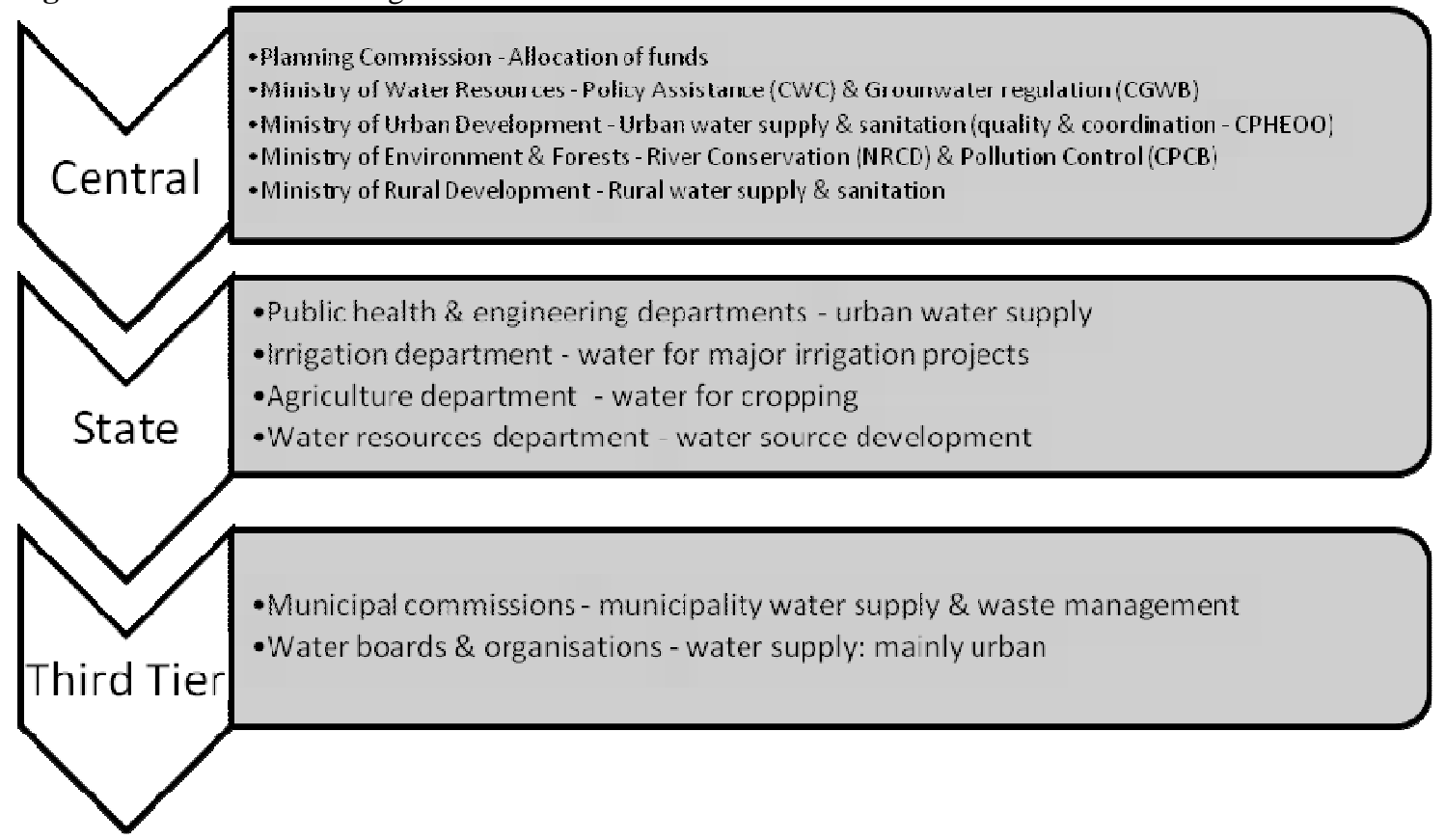

The quality of supply and cost efficiency of delivery of water services in urban areas has high variability (table 1). We now take a case of West Bengal (WB) state, which is closer to national average on all dimensions except tariff and metering (table 1), to ascertain the impacts of metering all water connections, its linkages with average tariff required to 
recover cost of water supply, impact of a cost plus water tariff system, its linkages with $24 \times 7$ water supply, and then draw conclusions for management of urban water systems at all India level.

\section{West Bengal's Urban Water Industry}

West Bengal is the most densely populated state of India at 1000 persons per square $\mathrm{km}$ (GoWB, 2010). Its average urban density is much higher at around 7500 persons per square $\mathrm{km}$ (figure 4). West Bengal has liberal water availability as a natural resource that supports intensive rain-fed agriculture. However the pressure on urban water resources has been increasing over some years due to increasing population, low investment in supply augmentation and dilapidating state of existing systems.

Figure 4: Population density of urban local bodies in West Bengal

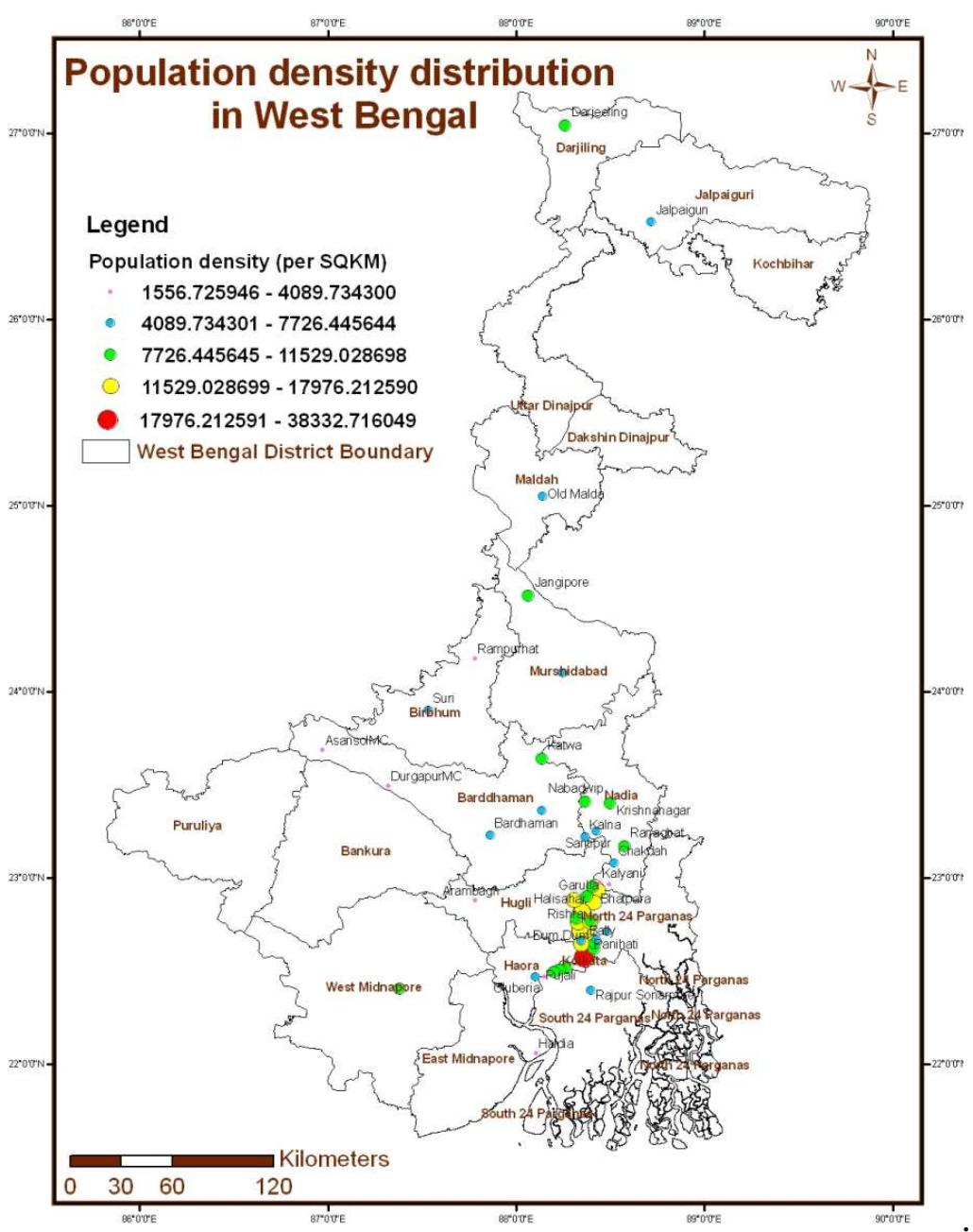

\subsection{Development of the water sector}

The State of West Bengal comprises of three distinct regions in terms of water resources North Bengal, Western Rarh and Eastern Bhagirathi. The basins of north Bengal consists 
of 63 per cent of state water resources while the Rarh and eastern plains carry 22 per cent and 15 per cent respectively (Rudra). In terms of urban water delivery, WB can be divided into two separate areas - Kolkata Metropolitan Area (KMA) and non- KMA area. The KMA area consists of 41 urban local bodies (3 Municipal Corporations including Kolkata Municipal Corporation and 38 Municipalities) out of 127 in WB, the rest being under the non-KMA area.

The urban water supply in the KMA area has been the responsibility of Kolkata Metropolitan Development Authority (KMDA) while the supply in the non-KMA area was handled by the public health and engineering department (PHED) till recently before the devolution of power to the local authorities. Following the $74^{\text {th }}$ constitutional amendment in 1992 and financing schemes like Jawaharlal Nehru National Urban Renewal Mission (JNNURM) from the central government, a slow devolution of authority has been taking place to the local governments. According to the JNNURM report for West Bengal, the responsibility for operation and maintenance for water supply and sanitation systems has been devolved to 86 of the 127 urban local bodies (ULBs) in the state. Also some of the ULBs such as Nabadiganta Industrial Township Authority (NDITA) which comprises of mainly industrial and commercial consumers in the IT and ITeS industry have entered into arrangements with private players for setting up and maintaining the water supply and waste evacuation systems.

KMA covers an area of $1851 \mathrm{sq} . \mathrm{km}$. and caters to a population of 14.7 million out of a total 22.5 million urban population across WB according to 2001 census (KMDA, KMWSA, 2010). Water in the KMA area is sourced from two sources - river Hoogly, the only surface water source and rest is procured from ground water. Treated water from the river is supplied through pipelines to a limited area of KMA, the majority of areas depending on ground water from deep tube-wells connected to a network of reservoirs and pipelines (City Development Plan, Kolkata).

The capital of the state, the city of Kolkata has one of the oldest water supply systems in India. Previously, the water supply system in the region depended on wells, tanks and nearby rivers. In 1773, the city of Kolkata was declared as the capital of British occupied India. However, it was only in 1820 that a small pumping station and a system of open masonry aqueducts was constructed (Dasgupta, Bhattacharya, Basu, Chatterjee, Banerjee, 1991). By 1870, most principal streets had access to piped water through 500 standposts (KMWSA).

The largest ULB in WB - the Kolkata Municipal Corporation (KMC), has several major deficiencies in respect of water service delivery like intermittent supply, inadequate pressure, high leakage loss, high energy consumption and dependence on groundwater (Majumdar \& Gupta, 2007). The capital which has a better supply system compared to other municipalities also suffers from inadequate zonal mains and old networks in an advanced state of dilapidation (Sivaramakrishnan, 1993). This also leads to an additional problem of high transmission and distribution losses to the tune of 30\% (Rudra). 
A snapshot of the water supply scenario in the state is presented in the table and figure below. There is an increasing deficit of water requirement in the state and it is worthwhile to examine the efficiencies of various water delivery mechanisms in the state. Another interesting point to note is only $56 \%$ of the population is being supplied surface water, the rest depending on fast depleting groundwater sources. Also in terms of access, only $53 \%$ of the population has access to water within their premises. Also in terms of water quality, arsenic contamination is severe in South Asia particularly in Bangladesh and eastern India (Sekar, Randhir, 2009) including the state of West Bengal. Thus depending on groundwater sources has an additional impact on health issues in the state.

Table2: Water Requirement and supply in West Bengal

\begin{tabular}{lll}
\hline Year & $\begin{array}{l}\text { Water Requirement (Million } \\
\text { hectare meter, Mham) }\end{array}$ & Deficit \\
\hline 2000 & 10.85 & $38 \%$ \\
\hline 2011 & 13.02 & $48 \%$ \\
\hline 2025 & 16.60 & $59 \%$ \\
\hline
\end{tabular}

Source: Compiled from data of State Irrigation Department (Rudra)

Figure 5: Water supply in Urban West Bengal (4554045 Households)
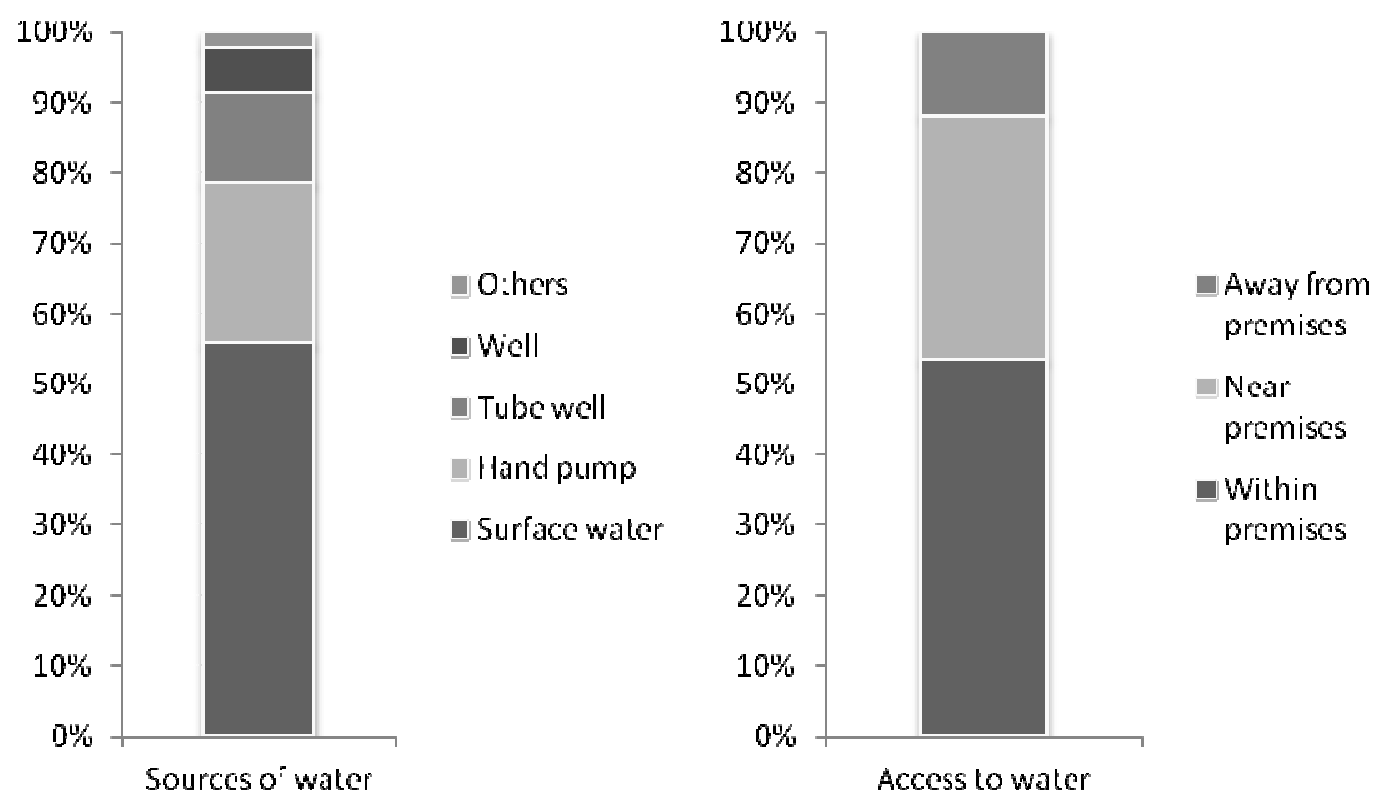

Source: Kolkata Development Report 2007, p170 (based on 2001 census data). 


\subsection{Institutional structure of water delivery}

"Urban water" in this study is taken to be potable water supplied by urban local bodies through their networks for both drinking and non drinking purposes. Till sometime back, the public health and engineering departments along with Kolkata metropolitan development authority used to be responsible for water supply in West Bengal. However, with devolution of authority to local bodies, the supply responsibilities and water delivery mechanisms are gradually taken up by these urban local bodies (ULBs). However there are considerable variances across these local institutions. The urban water organizations in West Bengal fall under 4 categories of local governance - municipal corporations, municipalities, notified area authorities and industrial townships. West Bengal Municipal Act, 1993 lays down the criteria for setting up an urban local body which includes population, population density, percentage of non-agricultural workforce and income from municipal taxation. Lists of broad groups of urban local bodies are provided in the table below:

Table 3: Grouping of urban local bodies

\begin{tabular}{lcl}
\hline Groups of Urban Bodies & Number & Specified areas \\
\hline Municipal Corporations & 6 & $\begin{array}{l}\text { Kolkata, Howrah, Asansol, Durgapur, } \\
\text { Chandannagore, Siliguri }\end{array}$ \\
\hline Notified Area Authority & 3 & Cooper's Camp, Taherpur and Mirik \\
\hline Industrial Township & 1 & Nabadiganta (Salt Lake) \\
\hline Municipalities & 117 & All others \\
\hline Total Urban Local Bodies & $\mathbf{1 2 7}$ & \\
\hline
\end{tabular}

Source: Department of Municipal Affairs, Government of West Bengal

The classification of urban local bodies into four major categories as discussed in table 3 is based on population, per capita income, percentage households involved in nonagricultural activities and other indicators. A population based classification also exists which groups urban bodies into five classes from A $-\mathrm{E}$ as defined in Section 7 of the West Bengal Municipal Act, 1993 (table 4).

Table 4: Category of urban local bodies used in West Bengal

\begin{tabular}{ll}
\hline Category & Population \\
\hline A & above $2,00,000$ \\
\hline B & above $1,50,000$ but not exceeding $2,00,000$ \\
\hline $\mathrm{C}$ & above 75,000 but not exceeding $1,50,000$ \\
\hline D & above 25,000 but not exceeding 75,000 \\
\hline E & not exceeding 25,000 \\
\hline
\end{tabular}

Source: Department of Municipal Affairs, Government of West Bengal 
The institutional structure of water delivery mechanism in the state is provided below.

Figure 6: Urban water Institutions in West Bengal

\begin{tabular}{|l|}
\hline \multicolumn{1}{|c|}{ Law } \\
\hline -West Bengal Municipal Act, \\
1993 \\
- West Bengal Municipal \\
Corporation Act, 2006 \\
- West Bengal Municipal \\
Corporation (Amendment) Act \\
2007 \\
- Acts of Municiapal Corporations \\
(Kolkata, Howrah, Siliguri, \\
Asansol, Durgapur, \\
Chandannagore) \\
-West Bengal Ground Water \\
Resources (Management, \\
Control and Regulation) Act, \\
2005 \\
-West Bengal Municipal Rules \\
2007 \\
- Nabadiganta Industrial \\
Township Authority Rules 2006 \\
- West Bengal Municipal \\
tlections Act, 1994
\end{tabular}

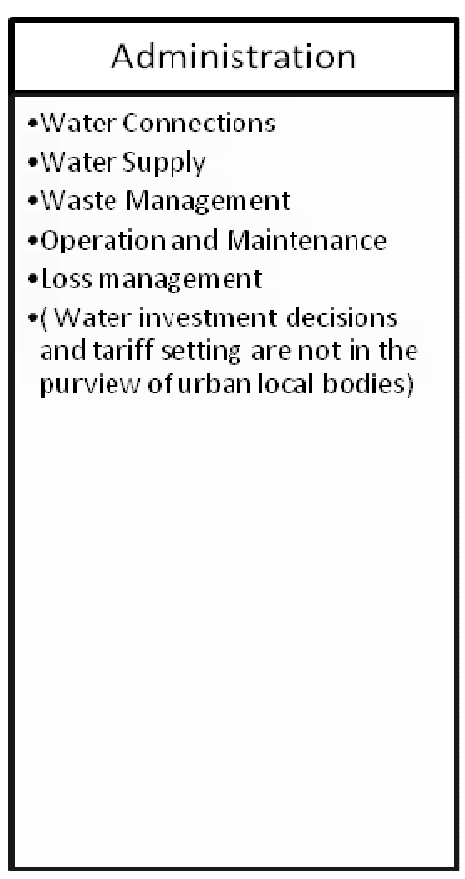

The West Bengal Municipal Act 1993 is a key legislation which lays down the rules for constitution of urban local bodies and guidelines for administration including supply of water and extraction of groundwater. The West Bengal Municipal Corporation Act 2006 lays down guidelines for municipal administration for the municipal corporations in the state except its capital, the city of Kolkata and its adjoining area Howrah. These two regions are solely guided by their own municipal legislations. This act makes it obligatory on part of the urban local bodies to construct and maintain water supply infrastructure in various localities. The legislation was amended in 2007. Apart from this, the six municipal corporations in the state have their own legislation and guidelines. The only industrial township at Salt Lake also has its own rules framed under the West Bengal Municipal Act 1993. The West Bengal Ground Water Resources (Management, Control and Regulation) Act, 2005 was introduced to control and regulate the usage of groundwater. Apart from West Bengal, other states like Tamil Nadu, Orissa and Maharashtra also has introduced similar legislations which set the stage for constitution of a groundwater authority to regulate the extraction of groundwater. The Municipal Rules (Section 171) provides a direction towards alternate water sources and mandates the use of rainwater harvesting systems.

The National Water Policy introduced at the federal level looks at planning, water resources development, water allocation priorities and private sector participation etc. among others. Many other Indian states have introduced their own water policies. However West Bengal is yet to introduce a comprehensive state water policy. Also many states in India have introduced draft legislations towards setting up of an independent water regulatory authority. Only the state of Maharashtra has so far set up an independent 
regulatory authority in India. However, this is also yet to take shape in the state. A comprehensive list of urban water institutions in West Bengal along with organizations responsible for water delivery is provided below.

In the present scenario, most of the urban local bodies are dependent on grants from the centre and the state governments for building up water delivery infrastructure. The setting of water tariff has been a much discussed area and not fully in the control of these local bodies. Thus at present, independent investment and tariff setting decisions do not rest with the local bodies and they are mostly focussed on operation and maintenance of the water supply infrastructure. A snapshot of the organizations responsible for water delivery in West Bengal is provided in Figure .

Figure 7: Water organizations in West Bengal

\section{State Government}

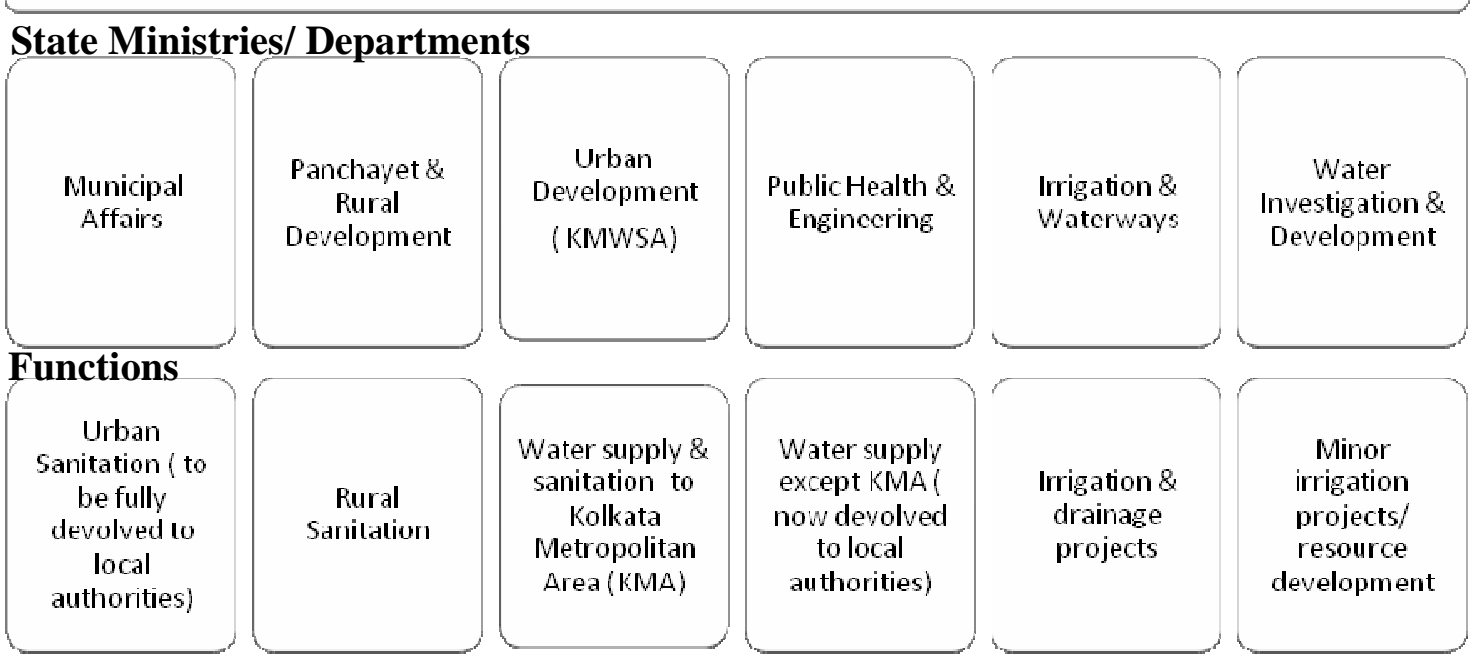

\subsection{Financing urban water}

A few studies have pointed out that many Indian cities charge water tariffs that cover only one tenth of the operational and maintenance costs (Raghupathi, Foster 2002). This renders the urban water systems un-remunerative for private sector participation and even the government finds it difficult to invest in capacity expansion and enhancing supply quality. Water supply in West Bengal is mostly not priced for a large number of domestic consumers. Only the high end domestic consumers, industrial and commercial consumers are covered in the tax net for water. Taking the case of Kolkata Municipal Corporation, the expenditure on water supply is over Rs. 1,100 million while only $20 \%$ of the cost is recovered (KMC, 2002). Non tax sources include onetime charge for water supply during the issue of trade license or sanction of building construction plans. Thus the sector has to depend heavily on grants from the centre and state governments. 
Various examples of such grants include the Jawaharlal Nehru National Urban Renewal Mission (JNNURM) which has a provision of Rs. 500,000 million over 7 years and covering 63 identified large cities in India. Also there are provisions for funds to be released on the recommendation of the state finance commission - the funds released amounted to Rs. 496 million in 2007-08. Though recovery of costs in the water sector in West Bengal through tariff mechanisms is not carried out at present, some local bodies have been exploring innovative mechanisms like private public participation to bring in private investment in the sector.

\subsection{Evidences of Private Participation in the state}

The National Water Policy 2002 encourages private participation and recommends various combinations of private involvement in building, owning, operating, leasing and transferring of water resources facilities (National Water Policy, 2002).

Private public partnerships in the water sector in India can be broadly classified into 5 categories - services contract, management contract, operation \& maintenance contracts, build-operate-transfer (BOT) contract and full private operation. Though there are evidences of all these forms existing in India, there is only a single private water sector utility i.e. Jamshedpur Utilities \& Services Company (JUSCO) is in operation catering to the water supply needs of the city of Jamshedpur. Recent trends in India indicate that BOT contracts are increasing and increasingly the private sector is taking up capital investment risks.

In West Bengal, Haldia Development Authority (HDA) has entered into a BOT agreement with Haldia Water Management Limited (HWML) - a joint venture company of JUSCO and Ranhill Utilities Berhard, a Malaysian water utility. The project involves a 25 year concession for setting up a 25 MGD water treatment plant and O\&M of the new and other existing facilities amounting to a total investment of Rs. 1000 million.

Another example of private participation involves a consortium of JUSCO and Voltas, who has taken up a 30 year BOT project to set up and maintain water supply and sewerage facilities in the salt lake area under Nabadiganta Industrial Township Authority (NDITA), an urban local body adjacent to the capital region of Kolkata. NDITA provides JUSCO with treated water from Kolkata Municipal Corporation at Rs. 5/ KL and JUSCO is allowed to recover Rs. 25/ KL as water supply and sewerage charges (KMDA, 2010). Apart from this the private player is also responsible for metering, billing and collection of the water supply and sewerage system. The following section carries out a benchmarking study of the urban local bodies in West Bengal focussing on water delivery efficiency under alternate institutional structures.

\section{Design of the benchmarking study}

The productive efficiency literature traces back to Farrell (1957) who first devised a methodology for constructing non-parametric cost efficiency indexes relative to a best practice production frontier. Later other approaches like the stochastic frontier have been devised by Aigner, Lovell and Schmidt (1977). Studies have identified three production frontier methodologies, which are suitable for benchmarking efficiencies of firms (Pollitt, 1997; Jamsab and Pollitt, 2001). They are i) the non-parametric approach or data 
envelopment analysis ii) parametric linear programming and iii) stochastic frontier method.

The data envelopment analysis (DEA) and stochastic frontier analysis (SFA) have been extensively used in studies involving the water sector. However, the parametric approach (that is stochastic frontier analysis) carries with it the risk of specification of the functional form and assumptions about distribution of the error term, which can be confused with inefficiency. Thus the DEA approach is used which allows us to avoid issues related to functional specification or assumption of the distribution of the error term. Whereas DEA is easier to construct, its non parametric property makes it difficult to analyze the effect of individual input parameters.

The present study uses the DEA approach to estimate efficiency levels of various ULBs in terms of water delivery. The analysis estimates the comparative efficiency of several decision making units by integrating multiple performance indicators into a single efficiency estimate.

Though a number of studies benchmarking water supply services exist in developed countries, there are very few studies focused on developing countries, particularly India. Early studies in developed countries have examined the relationship between efficiency and ownership of urban water utilities (Crain and Zardkoohi, 1978; Bruggink, 1982; Byrnes et al., 1986; Lambert and Dichev, 1993; Estache and Kouassi, 2002; Kirkpatrick et al., 2006). A study covering 27 Indian cities and using the DEA approach conclude that functional autonomy may have the potential to improve water services in developing countries like India (Gupta et. al., 2006). Another study based on 20 cities and also using DEA as a tool for analysis, concluded that length of the distribution network is one of the major determinants of performance of water utilities (Kumar, 2010).

\subsection{Estimation procedure}

Assuming that the water utilities controlled by ' $\mathrm{N}$ ' local governments uses ' $\mathrm{K}$ ' inputs $x=\left(x_{1}, \ldots \ldots \ldots x_{R}\right)$ to produce ' $\mathrm{M}$ ' outputs $y=\left(y_{1}, \ldots \ldots \ldots y_{m}\right)$. Thus the $\mathrm{K} \mathrm{x} \mathrm{N}$ input matrix $\mathrm{X}$, and the $\mathrm{Mx} \mathrm{N}$ output matrix $\mathrm{Y}$ represents the data for all the urban local bodies or DMU (decision making unit) as commonly referred to in the DEA literature. The objective of the modeling exercise to is to construct a non-parametric frontier envelope so that all the data points lie below or on the frontier. For each of the DMUs, we would ideally like to construct a ratio of all outputs to the ratio of all inputs $\frac{u^{x} y_{i}}{v^{s} x_{i}}$ with $u$ as an $\mathrm{Mx} 1$ matrix of output weights and $\mathrm{v}$ is a $\mathrm{Kx} 1$ matrix of input weights. To find the values for $\mathrm{u}$ and $\mathrm{v}$, the following linear programming model has to be set up

$$
\max _{u, v}\left(\frac{u^{l} y_{i}}{v^{l} x_{i}}\right)
$$

Subject to

$$
\frac{u^{x} y_{i}}{v^{x} x_{i}} \leq 1
$$




\section{$u, v \geq 0$}

The suffix $i$ denotes the $i^{\text {th }}$ DMU and $i$ varies from 1 to $N$. However, this form has an infinite number of solutions i.e if $\left(u_{1}, v_{1}\right)$ is a solution then $\left(\beta u_{1}, \beta v_{1}\right)$ is also a solution. To restrict the solution to a finite range, an additional constraint $\vartheta \cdot \mathbf{x}_{\mathbf{i}}=\mathbf{1}$ can be imposed by transforming variables $\mathbf{u}, \mathbf{v}$ to $\mu, \theta$ which can be taken as shadow prices. The resultant formulation of equation (1) is presented below.

$$
\max _{\mu, \theta} \mathbb{Z}\left(\mu^{7} y_{i}\right)
$$

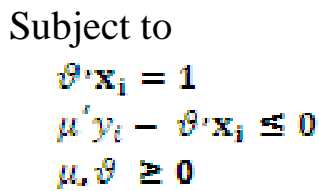

The above equation can be converted to the usual form of input oriented constant returns to scale (CRS) model using the duality in linear programming.

$$
\min _{\theta_{, y}} \theta
$$

Subject to

$$
\begin{aligned}
-y_{\mathrm{i}}+\mathrm{Y} \gamma & \geq 0 \\
6 \mathrm{x}_{\mathrm{i}}-\mathrm{X} Y & \geq 0 \\
\gamma & \geq 0
\end{aligned}
$$

Where $\theta$ is a scalar and represents the efficiency of the $i^{\text {th }}$ DMU.

$\theta$ satisfies the condition that $0 \leq \theta \leq 1 . \theta=1$ denotes that the respective DMU lies on the frontier and technically the maximum efficient. For example a technical efficiency or $\theta$ value of $70 \%$ would essentially indicate that the DMU can reduce its inputs by $30 \%$ without reducing its output as compared to its efficient peers.

$\gamma$ is a $\mathrm{N} \times 1$ vector of weights. This equation is solved $\mathrm{N}$ times, and a value of $\theta$ is assigned to each DMU in the sample. According to Farell (1957), though $\theta$ has been taken to be the technical efficiency, Koopman's (1951) efficiency definition also imposes an additional criteria i.e. in addition to the DMU being on the frontier, its slacks should also be zero for it to be termed efficient. This essentially means that to be termed efficient, according to Koopman's definition for an input oriented model the following two conditions need to be satisfied - a) $\theta=1$ and b) $\theta x_{i}-X y=0$

Some authors have thus suggested the use of a second stage programming model for maximizing the sum of slacks. But this solution is influenced by the unit of the variables apart from other issues. Thus for this paper we have adopted Farell's definition of efficiency and also have reported slacks so that Koopman's criteria can also be tested. 
The development of the above model assumes that all the DMUs operate at an optimal scale. However market imperfections and other factors may not render this condition true always. In such a condition if one employs a constant return to scale (CRS) model then the technical efficiencies suffer from the effects of scale efficiency. To mitigate the effect of scale efficiencies we use the variable returns to scale (VRS) model which has a convex frontier (compared to the conical one of CRS) and envelops the data in a better way than the CRS model. The variable returns to scale model is defined by including the following additional constraint in the CRS model:

$$
\sum \gamma_{1}=1
$$

The VRS technical efficiency (TE) score is equal or greater than that of CRS. Under the VRS model, a score of less than 1 indicates that it is neither technically efficient or scale efficient. On the other hand, a score of 1 may be purely due to technical efficiency and not scale efficiency.

To quantify the effect of scale efficiency we run both the CRS and the VRS specifications and compute the scale efficiency factor. The scale efficiency of the $i^{\text {th }}$ DMU can be computed as

$$
S E_{i}=\frac{T E_{i C A S}}{T E_{i V A S}}
$$

A scale efficiency of less than 1 indicates that the DMU has scale inefficiency which can be due to increasing or decreasing returns to scale. To further differentiate between increasing and decreasing returns to scale, a non-increasing returns to scale condition has been imposed by modifying the additional constraint for the DEA model from

$$
\sum \gamma_{i}=1 \quad \text { to } \sum \gamma_{i} \leq 1
$$

If the technical efficiency score from this specification is different from the original VRS technical efficiency score then one has to assume that there are evidences for increasing returns to scale. However if the two efficiency scores are equal then one has to assume that decreasing returns to scale are present.

We have modeled the DEA specifications with 4 different data sets with various combinations of inputs and outputs as described in the following section.

\subsection{Data description}

The data set for 126 urban local bodies were compiled from Urban West Bengal 20002002, published by the Institute of local government and urban studies, West Bengal 
(ILGUS, 2002). Other data sources include Status of Water Supply, Sanitation and Solid Waste Management in Urban Areas published by National Institute of Urban Affairs (NIUA, 2005) and reports published by the central pollution control board (CPCB, 2009, 2002, 1999, 1998). However, after compiling the data for 126 urban local bodies, it was found that only 55 of them were suitable for analysis, the others suffering from missing or inadequate data. Thus the DEA model was constructed with 55 urban local bodies. However the results of our analysis are representative for all ULBs since the 55 ULBs cover a wide spectrum for all the parameters.

The model specification is taken from previous benchmarking studies carried out in Malaysia by Susila Munisamy (Munisamy, 2005). The Malaysian study has used three inputs - operating expenditure, network length and volume of non-revenue water. The outputs used were volume of water delivered, number of connections and service area. However, as most of the water supply in WB is not metered, it is very difficult to get data on unaccounted for water. Thus total water supply is taken as an output of the water utilities which includes unaccounted for water. Other outputs are taken as number of connections and area serviced. The inputs are operating expenses, network length and number of employees. The data pertains to the period 2000-01, with the exception of the water supply parameter, which is collected over a period of 1998-2002 as consolidated data was not available. The input output parameters for the base case and subsequent cases are discussed below.

Base Case: The inputs include revenue expenses on water supply (salary, wages, and operation and maintenance expenses - this is taken as a proxy for a part of the cost of supply and can also be interpreted to be linked to a notional water tariff), capital expenses (network length being adopted as a proxy) and number of employees. The outputs include production from the water supply system namely the volume of water supply (in the absence of metering and data about unaccounted for water, this is taken to be a proxy for consumption) and number of house connections (taken as a proxy for water coverage). Service area is taken as a proxy for customer spread (Munisamy, 2005).

The input output parameters and summary statistics for the Base case are provided in the following table.

Table 2: DEA model parameters and summary statistics across 55 urban local bodies

$\begin{array}{llllll}\text { Parameters } & \text { Unit } & \text { Mean } & \text { Standard } & \text { Maximum } & \text { Minimum }\end{array}$
Deviation

\begin{tabular}{|c|c|c|c|c|c|c|}
\hline \multirow[t]{3}{*}{ Input } & $\begin{array}{l}\text { Annual } \\
\text { expenses on } \\
\text { water supply }\end{array}$ & $\begin{array}{l}\text { Rs. } \\
\text { Million }\end{array}$ & 5 & 5 & 29 & 0.1 \\
\hline & Network length & $\mathrm{km}$ & 179 & 416 & 3000 & 4 \\
\hline & $\begin{array}{ll}\text { Number } \\
\text { employees }\end{array}$ & No. & 921 & 5130 & 38252 & 7 \\
\hline \multirow[t]{2}{*}{ Output } & $\begin{array}{l}\text { Volume of } \\
\text { water supplied }\end{array}$ & MLD & 55 & 220 & 1625 & 0.0001 \\
\hline & Number & No. & 12511 & 32099 & 239000 & 80 \\
\hline
\end{tabular}


house

connections

\begin{tabular}{llllll}
\hline Service area & Sq. km. & 26 & 36 & 188 & 3 \\
\hline
\end{tabular}

Scenario 1: This is a variant of the Base case. The model is applied on the same dataset by interchanging two input output parameters. The volume of water supplied is taken as an input parameter (instead of output parameter in the Base Case) with the assumption that the volume of water supplied to each municipality could be driven by other factors such as minimum water requirement per capita, and not by the performance of a municipality. The annual expenses on water supply are taken as an output parameter (instead of an input parameter in the Base Case) to account for the fact that minimum notional tariffs should at least recover the cost of supply. This is treated as notional revenue for the urban local body from water supply.

Scenario 2: This scenario considers an institutional structure wherein input parameters such as number of house connections, network length, number of employees and service area cannot be easily changed upon by a particular ULB. These are thus taken as institutional constraints that a ULB has to service. These thus become input parameters for scenario 2 analysis. The outputs are taken to be those parameters which have to be varied to maintain a service level to these given input parameters. The output parameters thus are taken as volume of water supplied and annual expenses (as a proxy for revenue coverage).

A consolidated table of inputs and outputs for the various cases are provided below.

Table 3: DEA model input output parameters for various scenarios

\begin{tabular}{|c|c|c|c|}
\hline & Base Case & Scenario 1 & Scenario 2 \\
\hline \multirow[t]{4}{*}{ Input } & $\begin{array}{l}\text { Annual expenses } \\
\text { on water supply }\end{array}$ & $\begin{array}{l}\text { Volume of water } \\
\text { supplied }\end{array}$ & $\begin{array}{l}\text { Number of house } \\
\text { connections }\end{array}$ \\
\hline & Network length & Network length & Network length \\
\hline & No. of employees & No. of employees & No. of employees \\
\hline & & & Service area \\
\hline \multirow[t]{3}{*}{ Output } & $\begin{array}{l}\text { Volume of water } \\
\text { supplied }\end{array}$ & $\begin{array}{l}\text { Annual expenses } \\
\text { on water supply }\end{array}$ & $\begin{array}{l}\text { Annual expenses } \\
\text { on water supply }\end{array}$ \\
\hline & $\begin{array}{l}\text { Number of house } \\
\text { connections }\end{array}$ & $\begin{array}{l}\text { Number of house } \\
\text { connections }\end{array}$ & $\begin{array}{l}\text { Volume of water } \\
\text { supplied }\end{array}$ \\
\hline & Service area & Service area & \\
\hline
\end{tabular}

\subsection{Results}

The summary of the DEA analysis is presented in Fig 8 and the detailed results of the model constructed with 55 DMUs are provided in Table 8. The results indicate that all the three municipal corporations are operating at their maximum frontier efficiency which 
essentially means that these corporations are delivering best possible output in terms of service and delivery given the set of input resources. However, many urban local bodies belonging to $\mathrm{A}-\mathrm{D}$ category may not be operating at their maximum potential and there could be room for improvement, driven mostly by improvements in utilizations of networks and expenses. Surprisingly a category E city is on the frontier for the model considering variable returns to scale showing that some of the smaller local bodies can also operate at the frontier. This benchmarking study clearly demonstrates that for some local bodies there is scope for improving output services given the allocation of input resources. Also this means that if the output of these local bodies remains stagnant then there can be a mechanism to re adjust the input resource allocation. Thus this study suggests that in terms of water delivery, category A to D cities may be focussed upon for improvement. As the data was collected from various sources and the quality of the data could not also be verified through independently, the results may not reflect the true status of these urban local bodies at present. However, with improvement in data quality, this method of benchmarking can be carried out for urban local bodies for ensuring that they lie as close to the frontier as possible.

Figure 8: Summary of DEA efficiency scores across various categories of urban local bodies

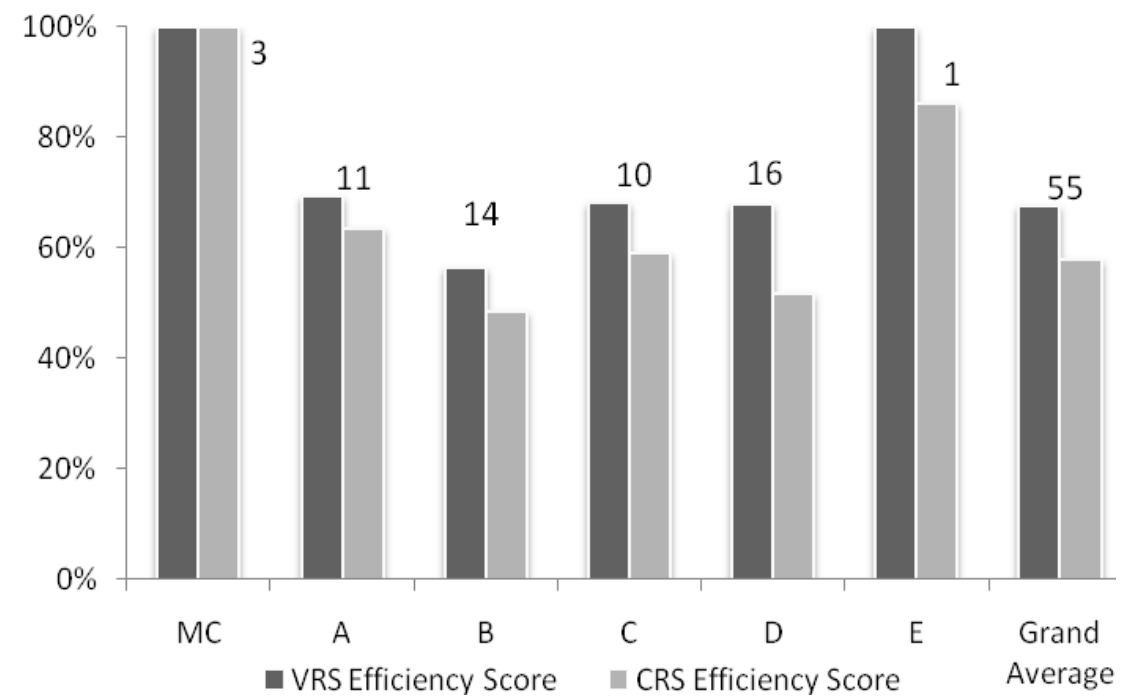

Note: MC denotes Municipal Corporation, A - E denote ULB categories, the figures above the charts denotes the number of ULBs considered for the study.

The results for the base case and scenarios are provided below for VRS efficiency scores. We have provided only the results for the VRS model as this takes into account the effects of scale efficiency and envelops the data in a better way than the CRS model.

Figure 9: Efficiency scores (VRS) for base case and scenarios 


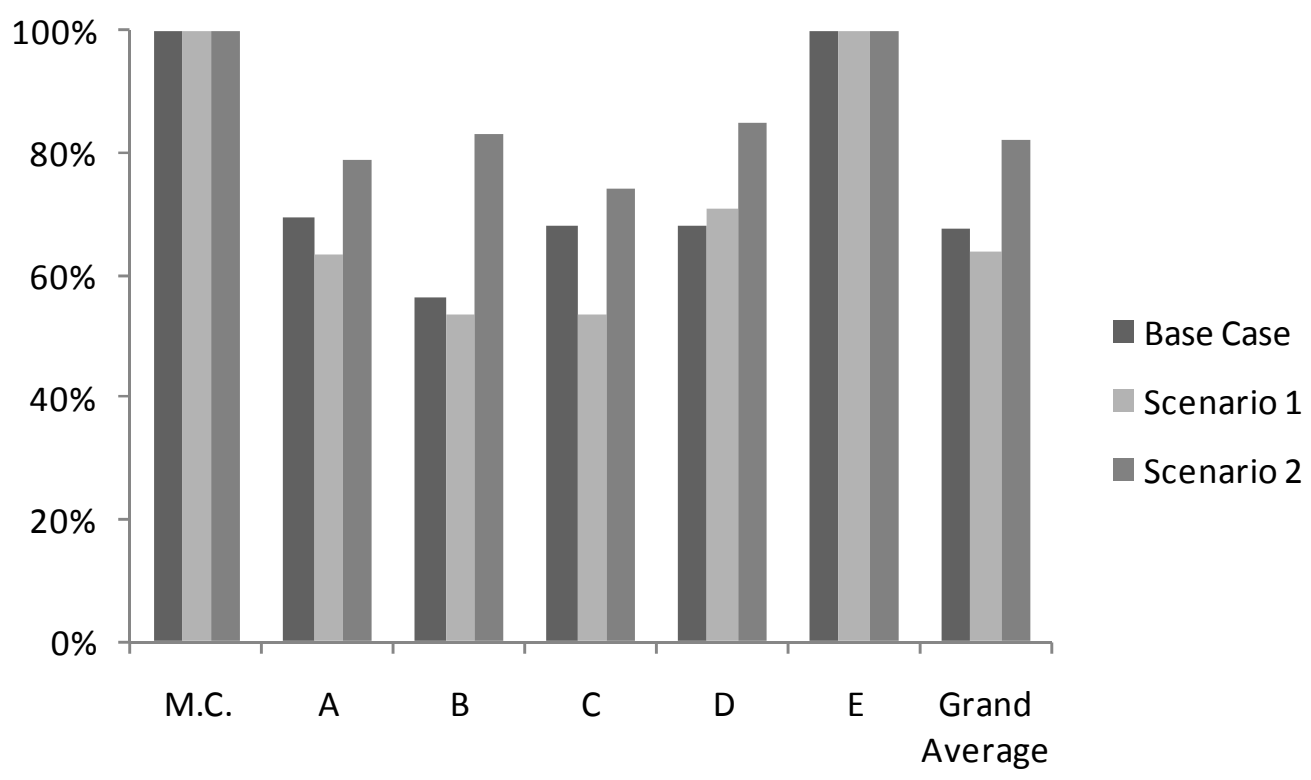

As mentioned in earlier, scope for improvement exists for categories A to D. This also brings into focus the need for defining which parameters can directly be controlled by the local body. Any changes in input and output parameters shall affect the model significantly and needs to be understood by the regulators. Scenarios 1 and 2 which take into account cost recovery imply that under a cost recovery regime, the ULBs operate closer to the frontier. Particularly scenario 2 which assumes a number of fixed input parameters and supply as an output implies that resource allocation (through the slow changing institutional process) needs to be closely examined for further efficiency gains. An improvement in VRS by over 50\% is noticed for 4 cities, viz. Katwa, Kamarhati, Bally and Rishra in scenario 1 compared to the base case, implying that monitoring cost of water as output and quantity of water as input could enhance efficiency of municipal operations. On the other hand, a decline over 50\% in scenario 1 VRS as compared to the base case is also noticed in 6 cities - Serampore, Maheshtala, Baharampore, Santipur, Rajpur-Sonarpur and Chakdah. This implies that the ULBs are either not recovering the cost of supply or are not able to supply the water requirement. Their operations are thus sub-optimal.

We also ran a variant of this scenario by changing the two parameters - namely the annual expenses on water supply to reflect Rs 15 per 1000 litres as water charges as against the present average of Rs 0.25 per 1000 litres; and volume of water supplied to reflect 135 litres per capita per day which is the average water consumption norms for urban areas. The technical efficiency values improved drastically for most of the ULBs. We need to thus study each ULB's water pricing and water supplied structure in detail to ascertain the optimal water requirement and water pricing to at least recover the cost of supply, making the ULBs operate more efficiently.

Senario 2, as compared to the base case, shows improvement over 50\% in 6 cities Kalyani, Kamarhati, Katwa, Bhadreswar, Bally and Konnagar. A decline over $50 \%$ is noticed in the Gayeshpur and Bardhaman. However the average efficiency of scenario 2 
is higher than both the base case and scenario 1 . This essentially implies that monitoring average cost of delivery and volume delivered could be a better way to improve water delivery efficiency of ULBs, specifically in a context where network lengthes, number of employees and institutional structures can not be altered due to various socio-political constraints.

\section{Conclusions and future extensions}

Based on our study of the institutional structure and benchmarking of the water industry in West Bengal, we have arrived at the following major conclusions. First, the capital city of Kolkata has the lowest percentage of connections metered and one of the lowest average water tariffs in India. As provided in table 1, we find that there is a close linkage between average tariff and percentage connections metered. Also metering is a precondition for imposing a tariff regime on water supply delivery.

Second, the benchmarking study indicates that large municipalities are operating at maximum possible efficiency, given the constraints on their inputs and outputs. There may be scope for efficiency improvement in many smaller ULBs. There is however a need to improve data quality for reliable benchmarking in future which could form a basis for resource allocation.

Third, the scenario analysis indicates that choice of inputs and outputs could have implications for benchmarking and efficiency of ULB operations, especially when cost recovery scenarios are introduced, the resource allocation and outputs needs to be carefully studied before arriving at a benchmark.

Fourth, an analysis of scenario 2 implies that given the level of outputs, the inputs are more efficiently allocated compared to both the base case and scenario 1 . This necessarily implies that unless institutional structures of municipal water supply systems are changed, which are traditionally slow changing, there is little scope of improving overall efficiency. Thus the water delivery network and connections need to be improved with reorganisation of human capital if required to achieve better efficiencies. Alternatively, the price of water supplied needs to be enhanced. There can also be scope for future studies to examine the reorganisation of the service area of these urban local bodies and understand if there could be any efficiency gains out of this exercise.

Fifth, the state of West Bengal and also other states in India need to shape up a water policy to provide an integrated direction to the development of the water sector. With a number of institutional overlaps and limited role of the urban local bodies in the planning process of the water supply system, a policy could provide broad guidelines to these fragmented institutions around water supply delivery.

Finally, though the water supply is historically mostly un-metered in Indian urban local bodies and a considerable portion of the water is not priced, there has to be a move towards cost recovery in a water scarce scenario. Thus the government can set into motion a process for setting up an independent regulatory authority for monitoring 
quality and pricing of water, at least to those portions of the population who have willingness and affordability to pay for quality water. 


\section{References}

1 ADB; 2007 Benchmarking and data book of water utilities in India, 2007.

2 Aguilar-Benitez, Ismael; Saphores, Jean-Daniel; Public accountability and performance of two border water utilities, Water Policy, Vol. 12, No. 2, pp 203-219, IWA Publishing, 2010.

3 Aigner, Lovell and Schmidt, Formulation and estimation of stochastic frontier production function models. Journal of Econometrics, Volume 6, Issue 1, July 1977,

Pages 21-37

4 Araral, Eduardo Jr. Public Provision for Urban Water: Getting Prices and Governance Right, Governance: An International Journal of Policy, Administration, and Institutions, Vol. 21, No. 4, October 2008 (pp. 527-549).

5 Araral, Eduardo; Reform of water institutions: review of evidences and international experiences, Water Policy, Vol. 12, No S1, pp 8-22, IWA Publishing, 2010.

6 Barlow M and Clarke T.; Who Owns Water? The Nation. September 2, 2002

7 Biswas, Asit K. Water Management for Major Urban Centres, Water Resources Development, Vol. 22, No. 2, 183-197, June 2006.

8 Bruggink,T.; Public versus private enterprise in municipal water industry: a comparison of operating costs., Quaterly review of economics and business 22 (1), 111-125, 1982.

9 Bureau of Applied Economics \& Statistics, Government of West Bengal.

10 Byrnes, P.; Grosskopf, S. and Hayes, K. Efficiency and ownership: further evidence. The Review of Economics and Statistics, 68, pp. 337-341, 1986.

11 Crain, W. and Zardkoohi, A., A test of the property-rights theory of the firm: water utilities in the United States. Journal of Law and Economics 21(2), 395-408, 1978.

12 Central Pollution Control Board (CPCB); Status of Water Supply and Wastewater Generation, Collection, Treatment and Disposal in Class-II Towns, No. CUPS/49/992000, 1999.

13 Central Pollution Control Board (CPCB); State of Water Supply and Wastewater Generation, Collection, Treatment and Disposal in Class - I Cities, No. CUPS/44/1998-99, 1998.

14 Central Pollution Control Board (CPCB); Municipal Sewage Pollution Along Indian Coastal Waters, No. COPOCS/27/2002-03, 2002.

15 Central Pollution Control Board (CPCB); Status of water supply, wastewater generation and treatment in class-I cities \& class-II towns of India, No. CUPS/ 70 / $2009-10,2009$.

16 City Development Plan, Kolkata

17 Development and planning department, West Bengal; http://wbplan.gov.in/

18 Estache, Antonio and Kouassi, Eugene, Sector Organization, Governance, and the Inefficiency of African Water Utilities (September 2002). World Bank Policy Research Working Paper No. 2890. Available at SSRN: http://ssrn.com/abstract $=636253$ 
19 Farrell, M. J.; Journal of the Royal Statistical Society. Series A (General), Vol. 120, No. 3, pp. 253-290, 1957

20 Government of West Bengal; Economic Review 2009-10, 2010.

21 Gupta, S.; Kumar, S.; Sarangi, G. K.; Measuring the performance of water service providers in urban India: implications for managing water utilities, National Institute of Urban Affairs, 2006.

22 IPCC, 2007: Climate Change 2007: The Physical Science Basis. Contribution of Working Group I to the Fourth Assessment Report of the Intergovernmental Panel on Climate Change [Solomon, S., D. Qin, M. Manning, Z. Chen, M. Marquis, K.B. Averyt, M.Tignor and H.L. Miller (eds.)]. Cambridge University Press, Cambridge, United Kingdom and New York, NY, USA.

23 Institute of local government and urban studies (ILGUS), Urban West Bengal 20002002, Kolkata, Saraswaty Press Ltd., 2002.

24 Jamasb, T.J., Pollitt, M.G., Benchmarking and regulation: international electricity experience. Utilities Policy 9 (3), 107e130, 2001.

25 JNNURM; JNNURM Data on West Bengal, http://www.jnnurmwestbengal.gov.in/

26 Kirkpatrick, C.; Parker, D. and Zhang, Y.F. An empirical analysis of state and private sector provision of water services in Africa The World Bank Economic Review, 20, pp. 143-163, 2006.

27 KMDA, West Bengal; http://www.kmdaonline.org/

28 KMWSA, West Bengal; http://www.kmwsa.gov.in/

29 KMDA; KMDA News, Vol. 1, No. 2, April 2010.

30 Koopmans, T.C., Analysis of production as an efficient combination of activities. In: Koopmans, T.C. (Ed.), Activity Analysis of Production and Allocation, Cowles

Commission, Wiely, New York, pp. 33-97, 1951.

31 Kumar, S; Unaccounted for water and the performance of water utilities: an empirical analysis from India, Water Policy, 2010

32 Lambert, D.K.and Dichev D, Ownership and sources of inefficiency in the provision of water services Water Resources Research, 29, pp. 1573-1578, 1993.

33 Majumdar C and Gupta,G.; Willingness to pay and municipal water pricing in transition: a case study. Journal of Integrative Environmental Sciences, 6:4, pages 247-260, 2009.

34 Munisamy S., Efficiency and Ownership in Water Supply: Evidence from Malaysia. International Review of Business Research Papers Vol. 5 No. 6 November 2009, Pp.148-260.

35 Nallathiga, R., Reforming Urban Water Supply Sector in India, The Icfai University Journal of Infrastructure, Vol. VI, No. 2, 2008.

36 National Institute of Urban Affairs (NIUA); Status of Water Supply, Sanitation and Solid Waste Management in Urban Areas, June 2005.

37 National Water Policy, Ministry of Water Resources, Government of India, New Delhi, 2002

38 North, D. C. 1981. Structure and change in economic history. New York, Norton

39 North, D. C., Economic performance through time. American Economic Review 84:3, 359-68, 1994. 
40 Planning Commission, India Assessment 2002: Water Supply \& Sanitation, Planning Commission, Government of India, 2002.

41 Pollitt, M., 1997. Ownership and performance in electric utilities: The international evidence on privatization and efficiency, Oxford University Press.

42 Raghupati, Usha P. and Foster V. Water: A Scorecard for India, Water Tariffs and Subsidies in South Asia Paper 2, Water and Sanitation Program-South Asia, 2002.

43 Saletha, R. Maria, Dinar, Ariel, Institutional changes in global water sector: trends, patterns, and implications, Water Policy, Vol 2, 2000, p175-199.

44 Sekar, I; Randhir, T; Arsenic contamination in water resources: mitigation and policy options, Water Policy, Vol. 11, pp 67-78, IWA Publishing, 2009.

45 Sivaramakrishnan K.C., ed; Managing Urban Environment in India, New Delhi, Times Research Foundation, 1993

46 The Economist, A special report on water, May 22, 2010

47 Urban development department, West Bengal; http://www.wburbandev.gov.in/

48 West Bengal department of municipal affairs; http://www.wbdma.gov.in/ 